\title{
PENERAPAN TEKNOLOGI PENGOLAHAN TOMAT MENJADI PRODUK BERNILAI EKONOMI DI DESA GUMANTAR KABUPATEN LOMBOK UTARA
}

\author{
Rucitra Widyasari ${ }^{*}$, Yeni Sulastri, Zainuri, M Abbas Zaini, dan Rini Nofrida \\ Program Studi Ilmu dan Teknologi Pangan Fakultas Teknologi Pangan dan Agroindustri \\ Universitas Mataram \\ ${ }^{*}$ Korespondensi: rucitrawidyasari@unram.ac.id
}

Diterima 12 November 2018 / Disetujui 15 Desember 2018

\begin{abstract}
ABSTRAK
Manisan tomat kurma (tomakur) adalah satu solusi untuk meningkatkan harga tomat terutama pada saat panen raya, dengan teknologi yang sederhana dan peralatan yang mudah dan adanya dukungan pemerintah setempat diharapkan dapat mempercepat terwujudnya kemandirian pangan masyarakat terutama untuk meningkatkan kembali kehidupan ekonomi setelah bencana alam didaerah tersebut. Tomakur merupakan salah satu bentuk pengawetan produk pangan yang bersifat semi basah sehingga memiliki banyak keunggulan, selain bertekstur lunak dan plastis (mudah dibentuk), jenis pangan ini juga dapat langsung dikonsumsi tanpa dehidrasi dan dapat disimpan tanpa harus disterilisasi, pendinginan maupun pengeringan. Kondisi alam dan telah ditetapkannya desa Kayangan sebagai salah satu daerah tanggap bencana gempa bumi,maka produk ini sangat cocok diaplikasikan sebagai salah satu bentuk pangan darurat mengingat kandungan gula yang cukup tinggi sebagai sumber energi. Kegiatan pengabdian kepada masyarakat telah dilaksanakan dengan mengambil lokasi di DusunAmor-amor Desa Gumantar Kecamatan Kayangan dengan melibatkan ibu - ibu yang tergabung dalam Kelompok Perempuan Tani. Peserta diberikan penyuluhan tentang cara pengolahan pangan yang baik dalam menunjang kualitas manisan tomat kurma yang dihasilkan, penyuluhan tentang cara pengemasan yang baik, pelatihan singkat manajemen usaha, penentuan harga jual produk serta praktek pengolahan tomat menjadi manisan tomat kurma. Hasil kegiatan dinilai positif dengan proses yang berlangsung secara efektif. Hasil evaluasi ini juga menunjukkan bahwa kegiatan serupa ini perlu dilakukan kembali dilokasi yang sama dengan memanfaatkan sumbersumber lain dalam pembuatan manisan.
\end{abstract}

Kata kunci: Amor-amor, Kayangan, Tomakur

\section{PENDAHULUAN}

Dusun Amor-amor, Desa Gumantar termasuk salah satu Desa dari delapan (8) desa yang berada di Kecamatan Kayangan dengan luas wilayah 3.860 ha dan kondisi geografis yang didominasi wilayah persawahan. Gambaran kondisi perekonomian masyarakat Desa Gumatar didominasi oleh sektor pertanian meliputi pertanian, tanaman pangan, hortikultura 
dan pertanian perkebunan lainnya yang diikuti sektor-sektor lainya seperti peternakan, perdagangan dan jasa.

Tomat merupakan salah satu hasil pertanian dari Dusun Amor-amor yang banyak diusahakan oleh masyarakat akhirakhir ini namun produk olahan belum dikembangkan. Sebagian besar tomat dijual hanya dalam bentuk segar, sehingga harga yang diperoleh oleh petani sangat bervariasi, kadang sangat murah sehingga merugikan bagi petani. Disatu sisi tomat bukan merupakan tanaman yang produktivitasnya sangat dipengaruhi oleh cuaca lingkungan. Selain itu, derasnya pasokan hasil pertanian terutama dari pulau Jawa turut pula mendorong rendahnya daya jual tomat lokal.

Namun faktor utama yang menyebabkan turunya harga tomat adalah belum adanya pola tanam petani hortikultura. Sebagai contoh pada saat harga tomat tinggi hampir semua petani ikut menanam tomat sehingga harga tomat pada saat panen menjadi sangat rendah karena pasokan yang melimpah. Harga tomat di pasaran Lombok Utara bahkan mencapai $\mathrm{Rp} \quad 500-1.000 / \mathrm{Kg}$ ditingkat petani.

Salah satu usaha yang dapat meningkatkan harga tomat adalah dengan mengolah tomat segar menjadi produk yang lebih bernilai ekonomis, misalnya dengan pengolahan tomat menjadi manisan tomat atau yang lebih dikenal sebagai manisan tomat kurma (Tomakur). Dengan pengolahan juga maka daya simpan produk tomat menjadi lebih panjang dan diharapkan pemasaran akan lebih luas, selanjutnya diharapkan mampu meningkatkan perekonomian masyarakat Dusun Amor-amor.

Kelompok masyarakat yang terlibat dalam pengembangan industri tomakur adalah ibu-ibu yang tergabung dalam Kelompok Perempuan Tani Karya Ibu yang ada di Dusun Amor-amor Desa Gumantar. Kelompok wanita yang bergerak dalam pemberdayaan ekonomi masyarakat ini memiliki potensi yang besar dalam menggerakkan ibu-ibu dan remaja putri untuk ikut aktif terlibat dalam program yang dilaksanakan.

\section{METODE KEGIATAN}

\section{Waktu dan Lokasi}

Kegiatan pengabdian dilaksanakan pada bulan November 2018. Lokasi kegiatan sesuai dengan potensi bahan baku di lokasi mitra yaitu di Dusun Amoramor Desa Kayangan Kabupaten Lombok Utara.

\section{Alat dan Bahan}

Peralatan yang digunakan dalam kegiatan ini berupa alat pengolahan dan kemasan untuk mengolah manisan tomat (tomakur) yang terdiri dari: hand sealer, kompor, wajan, kemasan plastik, pisau, saringan, suthil, sendok, tabung gas $3 \mathrm{Kg}$, timbangan, dan label. Bahan baku yang digunakan untuk pengolahan manisan tomat adalah tomat matang, gula pasri, gula merah, kaur sirih dan air.

\section{Metode Pelaksanaan}

Kegiatan pengabdian kepada
masyarakat ini dilakukan melalui
serangkaian tahapan kegiatan yang
meliputi optimasi dan persampel produk
di laboratorium lalu dilanjutkan dengan
pelatihan kepada masyarakat. Kegiatan
pelatihan tersebut dilakukan dengan
metode ceramah, diskusi, dan dilanjutkan
dengan praktek pembuatan manisan
tomat (tomakur). Materi pelatihan yang


diberikan meliputi Sanitasi Dan Peranan CPPB (Cara Pengolahan Pangan yang Baik) dalam menunjang kualitas tomakur, Teknik Pengolahan Manisan tomat (Tomakur) dan Pengemasan dan labelling.

Evalusi kegiatan dilakukan dengan melihat tanggapan peserta dan kemampuan penguasaan materi yang telah diberikan. Tanggapan dan penguasaan materi diukur dengan kehadiran peserta, memantau pertanyaan yang disampaikan peserta kepada penyaji materi, serta keaktifan peserta saat melakukan praktek pembuatan manisan tomat (Tomakur).

\section{HASIL DAN PEMBAHASAN}

\section{Optimasi dan Penyiapan Sampel Produk Manisan Tomat}

Sebagai tahapan awal dalam pelaksanaan kegiatan pengabdian ini adalah tim melakukan optimasi teknologi pengolahan dan penyiapan sampel produk manisan tomat di Laboratorium Pengolahan Pangan Fakultas Teknologi Pangan dan Agroindustri Universitas Mataram. Kegiatan ini sangat penting agar dapat diperoleh prosedur pengolahan yang tepat untuk pengeringan yang dilakukan dan komposisi gula yang sesuai.

\section{Pelatihan Pengolahan Manisan Tomat}

Kegiatan pengabdian yang terdiri atas dua tahapan yaitu pemaparan materi lalu dilanjutkan dengan praktik pengolahan manisan tomat. Semua tahapan kegiatan telah dilaksanakan dengan baik sesuai dengan rencana, termasuk tentang materi, waktu, dan hasil yang diharapkan.. Ilustrasi proses penyampaian materi dan praktik pengolahan dapat dilihat pada Gambar 1.

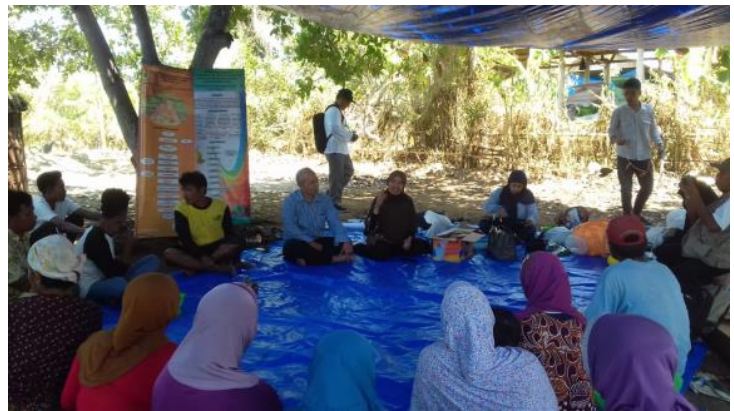

Gambar 1. Kegiatan penyampaian materi

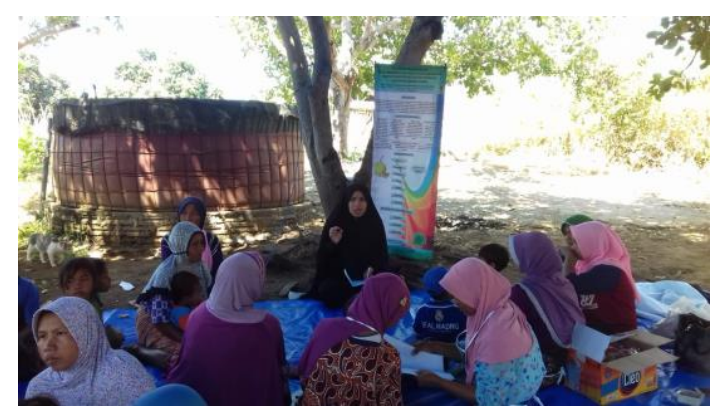

Gambar 2. Proses pembuatan manisan tomat

Kegiatan pelatihan berjalan dengan baik dan efektif. Peserta pelatihan sangat antusias dalam mengikuti kegiatan pelatihan. Hal ini ditunjukkan dengan tingkat kehadiran peserta serta keseriusan mereka selama kegiatan. Peserta menanyakan banyak hal kepada narasumber terkait dengan pengolahan buah pisang. Beberapa peserta menyatakan sangat ingin melaksanakan dan mempraktikkan pengetahuan yang diperoleh dan sangat berharap agar diberikan pembinaan lanjutan. Oleh karena itu, kegiatan pelatihan semacam ini perlu terus dilanjutkan di masa yang akan dating, tentunya dengan mempertimbangkan jenis produk yang disesuaikan dengan potensi daerah di lokasi kegiatan.

Untuk menambah wawasan anggota kelompok, pada saat acara pelatihan dihadirkan juga narasumber dari 
pakar Agribisnis agar dapat membantu menambah pengetahuan dan wawasan peserta terkait dengan analisis usaha dan pemasaran produk sehingga kelompok binaan dapat menjalankan usahanya dengan baik dan dapat meningkatkan produktivitas anggota masyarakat di sekitarnya.

Untuk mendukung kegiatan pelatihan dan pembinaan serta untuk membantu kelompok agar dapat mengembangkan usaha pengolahan buah pisang kedepannya, kelompok diberikan bantuan alat pengolahan berupa peralatan pengolahan yang utama termasuk wajan besar, slicer, alat pencetak adonan kulit sale lilit serta hand sealer yang digunakan untuk proses pengemasan produk agar produk siap dipasarkan. Penyerahan alat ke peserta pelatihan dapat dilihat pada Gambar 2 . Kegiatan pengabdian ini sangat didukung oleh pemangku kebijakan di Desa (Kades dan Kadus, serta tokoh masyarakat) sehingga prospek keberlanjutan usaha kelompok menjadi sangat bagus.

\section{Pembinaan Mitra}

Untuk mendukung keberlangsungan usaha pengolahan manisan tomat yang dilakukan oleh kelompok, maka tim pelaksanaan kegiatan melakukan kegiatan pembinaan. Kegiatan pembinaan ini sangat penting agar produk mansion tomat yang dihasilkan oleh kelompok agar memenuhi syarat mutu dan keamanan pangan sesuai dengan standar yang dikeluarkan oleh pemerintah.

\section{Faktor Pendukung dan Penghambat Kegiatan Pengabdian}

Keberhasilan pelaksanaan kegiatan pengabdian ini didukung oleh beberapa fakor antara lain:
1. Antusiasme dan kesadaran peserta untuk meningkatkan dan menumbuhkan kembali perekonomian mereka. Faktor ini menggerakkan mereka untuk mengikuti kegiatan pelatihan dan kemudian mengaplikasikan untuk mengembangkan pengolahan buah tomat menjadi tomakur. Kesadaran dan antusiasme ini merupakan hal yang penting dalam salah satu tahapan untuk penerapan teknologi atau inovasi bagi masyarakat.

2. Masyarakat di Dusun Amor-amor merupakan masyarakat yang suka bekerjasama dalam melaksanakan suatu kegiatan dan saling membantu untuk menyelesaikan suatu masalah yang dihadapi oleh masyarakat. Dalam kondisi bencana mereka bersamasama membangun kembali rumah mereka, tempat beribadat bahkan membuat tempat berkumpul untuk melaksanakan pengabdian secara swadaya. Kondisi ini merupakan modal untuk maju bersama dalam suatu bisnis. Dengan kebersamaan maka banyak masalah yang bisa diselesaikan dan umumnya pekerjaan menjadi lebih ringan.

3. Kegiatan ini memberi nilai tambah bagi komoditas tomat dan memberikan keuntungan untuk menghasilkan produk yang lebih bermutu dan menguntungkan telah dapat dilihat oleh peserta kegiatan, sehingga mereka menjadi mau untuk menerapkan teknologi yang disampaikan.

4. Dukungan pemerintah daerah. Pemerintah daerah Kabupaten Lombok Utara turut memfasilitasi pengembangan usaha kecil melalui penyediaan Pasar UKM sehingga 
masyarakat yang mengembangkan bisnis dapat memasarkan produknya.

Sebaliknya ada juga faktor penghambat kegiatan. Faktor penghambat ini antara lain:

1. Keterlambatan pelaksanaan karena faktor bencana alam, gempa bumi yang melanda NTB selama kurang lebih 90 hari dengan kerusakan terberat di Desa Kayangan menyebabkan pelaksanaan pengabdian terhambat.

2. Akibat hal tersebut peserta pelatihan sibuk dengan kegiatan membenahi rumah tempat tinggal mereka, menyelamatkan hewan ternak, hasil bumi dan rumah tinggal sementara.

3. Faktor-faktor yang menghambat ini perlu dipikirkan pemecahannya, pengabdian dengan hambatan bencana alam bukanlah sesuatu yang dapat diprediksi, sehingga ke depannya kegiatan pengabdian seharusnya benar-benar apa yang dibutuhkan secara mendesak oleh peserta, seperti kegiatan bakti sosial.

\section{KESIMPULAN DAN SARAN}

\section{Kesimpulan}

Dari kegiatan pelaksanaan Pengabdian Pada Masyarakat "Penerapan Teknologi Pengolahan Tomat Menjadi Produk Bernilai Ekonomi di Dusun AmorAmor Desa Gumantar $r$ Kabupaten Lombok Utara" dapat disimpulkan bahwa kegiatan yang dilakukan berhasil, hal ini terlihat dari lancarnya dan efektifnya waktu yang digunakan. Indikator keberhasilan kegiatan juga terlihat dari keseriusan ibu-ibu kelompok perempuan tani dalam mengikuti pelatihan serta dalam setiap diskusi selalu memberikan pendapat serta pertanyaan terhadap keingintahuan mereka dalam mengaplikasikan teknologi tepat guna tersebut.

\section{Saran}

Pelatihan pembuatan tomakur diharapkan mampu meningkatkan keterampilan "Kelompok Peremuan Tani" dan dapat menjadi alternatif pengolahan tomat, selain hanya dijual dalam bentuk segar sehingga dapat meningkatkan nilai jual terutama selama musim panen.

\section{UCAPAN TERIMA KASIH}

Penulis mengucapkan terima kasih kepada Universitas Mataram yang telah membantu dana (melalui Lembaga Penelitian dan Pengabdian Masyarakat) untuk pelaksanaan pengabdian dalam bentuk Dana DIPA PNBP (SPP/DPP/Dana Masyarakat) Universitas Mataram Tahun Anggaran 2018.

\section{DAFTAR PUSTAKA}

Desrosier, N. W., 1988. Teknologi Pengawetan Pangan. Penerjemah M. Muljohardjo. UI-Press, Jakarta.

Sinaga, R.M. 1984. Pengaruh Pemangkasan Batang Terhadap Mutu Buah Tomat Beberapa Varietas Tomat. Buletin Penelitian Hortikultura. 11 (3): 37-43.

Tugiyono, H. 2001. Bertanam Tomat. PT Penebar Swadaya. Jakarta.

Tonucci, L., M.J. Holden, G.R. Beecher, F. Khacik, C.S. Davis, and G. Mulokozi, 1995. Carotenoid Content of Thermally Processed Tomato Based Food Product. J. Agric, Food Chem. 43:579-586.

Winarno, F.G. 1986. Kimia Pangan dan Gizi. PT. Gramedia. Jakarta. 